\title{
A Survey of the Challenges of Translating Research Results into Classroom Practice on the teaching of Mathematics in Secondary Schools
}

\author{
Dr. Abiodun A. Popoola (Ph.D) \\ Associate professor, Department of Curriculum Studies, Ekiti State University, Ado Ekiti, \\ Ekiti State, Nigeria \\ Dr. Ajayi Peter O (Ph.D) \\ Department of Curriculum Studies, Ekiti State University, Ado Ekiti, Ekiti State, Nigeria \\ Mr. Ogundola Peter Ilesanmi \\ Department of Curriculum Studies, Ekiti State University, Ado Ekiti,, Ekiti State, Nigeria
}

Accepted: October 01, 2012 Published: October 26, 2012

Doi:10.5296/jsr.v3i2.2566 URL: http://dx.doi.org/10.5296/jsr.v3i2.2566

\begin{abstract}
This study examined extent to which teachers are able to translate the research results into classroom practice. This study sought data from three hundred classroom Mathematics teachers using a-30 item self constructed validated and reliable questionnaire which was found to be appropriate. The instrument sought information on the teacher's awareness of the various research reports and their assessments of the problems facing translating findings to classroom practice. Preliminary findings indicate that majority of teachers are not aware of these research results. They find the application of these results difficult and are skeptical of the efficacy of the new methods recommended in such reports. It was suggested that research results should be made available for public consumption; should be less difficult to use for classroom practice; and that policy makers to step up efforts in assisting teachers to use the research findings in their teaching.
\end{abstract}

Keywords: translating research results, findings, classroom practice, challenges, teachers, teaching, awareness, mathematics 


\section{Introduction}

There have been decades of research into the improvement of Mathematics teaching in Nigeria and elsewhere. The focus of these studies ranged between curricular, use of instructional materials, assessment, applicability of methods, use of new methods/innovations and many others. It is believed that, if adopted and implemented, the findings from these studies are capable of transforming the Mathematics classrooms into bastions of best practice and turn Mathematics teachers and their students into Mathematics experts. Somewhat surprising, the results of students in Mathematics at the ultimate national examinations do not indicate any dramatic positive change in the performance of students and there are no evidences that students are happier during mathematics lessons or are more enthusiastic in learning the subject.

The purpose of this paper is to investigate the challenge in the translation of research results into classroom practice in mathematics among Mathematics teachers in Nigeria.

Many studies have documented various issues which constitute barriers to translating research findings into day-to-day practices in the classroom. According to Heid Middleton, Larson, Gutstein, Fey, King, Strutchens, \& Tunis, (2006) many teachers of Mathematics have little time for, or experience in reading and interpreting research on teaching and learning. They also find it difficult to translate those findings into practice in teaching their subject. The lack of time for reading research results and interpreting them among teachers could have been informed by the fact that the day-to-day activities of the teachers are often externally determined. For instance, the school calendar, opening hours, the amount of time available for work, the reading materials and even the curriculum are prescribed by government officials outside of the school and teachers were not necessarily consulted in deciding on these issues. This situation is further compounded by the complaints of overwork by teachers. Naylor ${ }^{* *}$ ) for example had documented that teachers are overworked as one of the things that could stand in the way of translating research into classroom practice. According to the study, Teachers and researchers come from different paradigms; while teachers prefer a more normative and practical perspective, the researcher's perspective is usually analytical and while the teacher is faced with seeking solution to particular situations, the researcher is always seeking to generalise. The result of these differences in the perspective of the practicing teacher and the professional researcher is that, many teachers tend to see research findings as addressing solutions to problems that are not relevant to their own day-to-day needs. The implications of this situation is that, if the research findings are to be useful to classroom practices, practitioner based questions must predominate. Burkhardt and Schoenfield ,2003) had argued this point and offered that greater emphasis on classroom based research would be more useful in understanding the role of contextual factors in the teaching and learning of Mathematics. Predominating research with more extensive classroom-based research however, is likely to be faced with many challenges. For examples, school authorities may not be prepared to allow their classrooms to be turned into laboratories for yet to be verified hypotheses. They may not be willing to fritter away available time in 
view of specific daily time work-schedule and syllabi. These cultural differences between teachers and research people and the methodological difficulties could constitute communication barriers between the teachers and the research community making research findings inaccessible to teachers and those issues of interest to teachers hidden to the research people. Yet, Huberman, (1992) had showed that 'sustained interactivity' among researchers and teachers (practitioners) is more likely to lead to more research utilization. When teachers and researchers interact repeatedly during the course of the research, the meaning and validity of the study are negotiated by both parties. What this translates into is that researchers should work with teachers to develop research agenda; teachers work with researchers in conducting research; both work together in deriving meaning from the research findings and also work together in the dissemination process. This can be very challenging. Apart from already identified barriers to implementation of research findings in the classroom, others exist that may lie within the teachers, and/or within the system. For instance, teachers may be unaware of the research findings. Research findings have little impact if teachers are not aware of them. Teachers must have copies of these findings which have been translated or accompanied with guidelines on their use. They need to be familiar enough with the details to use them correctly. Are there any provisions for this by the system?

\section{Research Questions}

1 Are teachers aware of the research results on teaching methods?

2 Are research results useful and relevant to the level of the mathematics teachers?

3 What are the challenges to the translation of research results into classroom practice?

4 What are the relative contributions of research challenges to classroom practice?

\section{Methodology}

The research design was a survey type which used questionnaire to collect information from subjects. The population of the study consisted of all Mathematics teachers in the State. Teachers in 30 Schools were included in the sample taken from five of the 16 Local Government Areas (LGAs) in the State. In all,189 teachers spread among both senior and Junior Secondary Schools in the study area completed the questionnaire. The qualification of the Teachers ranged from National Certificate in Education (NCE) to University degrees in Mathematics Education.

The research instrument was a questionnaire developed by the researchers. The main body of the instrument consisted of items which solicited information on the teachers' awareness of the various research reports on methods, usefulness, relevance and challenges in attempt to make use of the findings among others. The instrument contained 30 items in all. The questionnaire was appropriately validated by three experts in Mathematics education and Tests and Measurements. The reliability coefficient of 0.94 was obtained which was found to be reliable and suitable for the study. 
The instrument was administered on the respondent in the school with the help of research assistant. Data collated were pre-coded, entered and analyzed with the statistical package for social science (SPSS) version 15. Frequency counts, percentages and multiple Regressions were used as tools of analysis.

\section{Results}

Question 1: Are teachers aware of the research results in teaching methods?

Table 1: Teachers' awareness of research results in teaching methods

\begin{tabular}{|c|c|c|c|c|c|c|c|c|c|}
\hline \multicolumn{2}{|c|}{ Teaching methods } & \multicolumn{8}{|c|}{ Awareness } \\
\hline & & \multicolumn{2}{|c|}{ Frequently } & \multicolumn{2}{|c|}{ Often } & \multicolumn{2}{|c|}{ Seldom } & \multicolumn{2}{|c|}{ Never } \\
\hline & & $\mathrm{f}$ & $\%$ & $\mathrm{~F}$ & $\%$ & $\mathrm{~F}$ & $\%$ & $\mathrm{~F}$ & $\%$ \\
\hline 1 & Problem solving & 94 & 47 & 47 & 24.9 & 6 & 3.2 & 42 & 22.2 \\
\hline 2 & Conversation & 51 & 24 & 39 & 20.6 & 11 & 5.8 & 88 & 46.6 \\
\hline 3 & $\begin{array}{l}\text { Heuristic } \\
\text { problem solving }\end{array}$ & 37 & 19.6 & 26 & 13.8 & 22 & 16.6 & 104 & 55.0 \\
\hline 4 & $\begin{array}{l}\text { Peer instructional } \\
\text { method }\end{array}$ & 36 & 19 & 28 & 14.8 & 30 & 15.9 & 95 & 50.3 \\
\hline 5 & Inquiry model & 45 & 23.8 & 31 & 16.4 & 20 & 10.6 & 93 & 49.2 \\
\hline 6 & Demonstration & 50 & 26.5 & 38 & 20.1 & 16 & 8.5 & 84 & 45.0 \\
\hline 7 & Field trip & 31 & 16.4 & 36 & 19 & 31 & 16.4 & 91 & 48.2 \\
\hline 8 & $\begin{array}{l}\text { Branching } \\
\text { programmed } \\
\text { instruction }\end{array}$ & 25 & 13.2 & 38 & 20.1 & 27 & 14.3 & 99 & 52.7 \\
\hline 9 & Individualistic & 23 & 12.2 & 37 & 19.6 & 26 & 13.8 & 103 & 54.4 \\
\hline 10 & Cooperative & 27 & 14.3 & 39 & 20.6 & 19 & 10.1 & 104 & 55 \\
\hline 11 & $\begin{array}{l}\text { Independent with } \\
\text { teacher direction }\end{array}$ & 29 & 15.3 & 29 & 15.3 & 16 & 8.5 & 115 & 60.9 \\
\hline 12 & $\begin{array}{l}\text { Systematic } \\
\text { approach }\end{array}$ & 27 & 14.3 & 28 & 14.8 & 18 & 9.5 & 116 & 61.4 \\
\hline 13 & $\begin{array}{l}\text { Problem based } \\
\text { learning }\end{array}$ & 22 & 11.6 & 33 & 17.5 & 15 & 7.9 & 119 & 63 \\
\hline
\end{tabular}




\begin{tabular}{|l|l|l|l|l|l|l|l|l|l|}
\hline 14 & $\begin{array}{l}\text { Discovery } \\
\text { learning }\end{array}$ & 19 & 10.1 & 32 & 16.9 & 19 & 10.1 & 119 & 63 \\
\hline 15 & Mastery learning & 18 & 9.5 & 27 & 14.3 & 27 & 14.3 & 117 & 61.9 \\
\hline 16 & Class audience & 19 & 10.1 & 28 & 14.8 & 11 & 5.8 & 131 & 69.3 \\
\hline 17 & $\begin{array}{l}\text { Independent } \\
\text { study }\end{array}$ & 22 & 11.6 & 22 & 11.6 & 16 & 8.5 & 129 & 68.2 \\
\hline 18 & $\begin{array}{l}\text { Questioning } \\
\text { method }\end{array}$ & 25 & 13.2 & 25 & 13.2 & 16 & 8.5 & 123 & 65.1 \\
\hline 19 & Participatory & 20 & 10.6 & 18 & 9.5 & 31 & 16.4 & 120 & 63.5 \\
\hline 20 & Drill & 38 & 20.1 & 18 & 9.5 & 25 & 13.2 & 108 & 57.1 \\
\hline & Overall & & 17.40 & & 16.40 & & 10.90 & & 55.30 \\
\hline
\end{tabular}

Table 1 shows respondents agree on only one 94(47\%) out of twenty teaching methods in Mathematics, why respondents disagree on the awareness of the teaching methods in Mathematics with the sixteen of the methods with the percentage greater than $50 \%$. This implies that majority of the respondents claim never aware of the research results in the teaching methods in Mathematics which was found to be $55.30 \%$ this is followed closely by often awareness of teaching methods of $16.4 \%$. Only $17.40 \%$ of the respondents frequently agree to be aware of the research results in teaching methods in Mathematics, while the least awareness responses of the respondents are found to be $10.0 \%$.

Question 2: Are research results relevant to the level of the Mathematics teachers?

Table 2: Relevance of research results to the level of Mathematics teachers

\begin{tabular}{|l|l|l|l|l|}
\hline Item & \multicolumn{2}{l}{ Agree } & \multicolumn{2}{l|}{ Disagree } \\
\cline { 2 - 6 } & $\mathbf{F}$ & $\mathbf{\%}$ & $\mathbf{F}$ & $\%$ \\
\hline $\begin{array}{l}\text { Most research results develop students' skills and } \\
\text { cognitive abilities }\end{array}$ & 158 & 83.6 & 31 & 16.4 \\
\hline Most research results can be applied in the classroom & 44 & 23.3 & 145 & 76.7 \\
\hline $\begin{array}{l}\text { Recent researches enhanced the knowledge of both } \\
\text { teachers and students }\end{array}$ & 96 & 50.8 & 93 & 59.2 \\
\hline $\begin{array}{l}\text { Teachers find research findings relevant to classroom } \\
\text { practice }\end{array}$ & 90 & 47.7 & 99 & 52.4 \\
\hline $\begin{array}{l}\text { Teachers improve on mathematical ideas when } \\
\text { exposed to research findings on method of teaching }\end{array}$ & 172 & 91 & 17 & 9 \\
\hline $\begin{array}{l}\text { Exposure to research results improves teachers' } \\
\text { potentialities in classroom practice }\end{array}$ & 173 & 91.5 & 16 & 8.4 \\
\hline Overall & & 64.56 & & 35.44 \\
\hline
\end{tabular}

Table 2 shows the relevance of research results to classroom practice. The overall majority of 


\section{Macrothink}

the respondents agreed on the relevance of research results to classroom practice with $64.56 \%$. Only $35.44 \%$ respondents disagreed that research results are not relevant to classroom teaching.

Question3. What are the challenges to the translation of research results into classroom practice?

Table 3: Challenges of translating research results into classroom practice

\begin{tabular}{|l|l|l|l|l|}
\hline Challenges & \multicolumn{2}{l}{ Agree } & \multicolumn{2}{l|}{ Disagree } \\
\cline { 2 - 6 } & F & \% & F & \% \\
\hline Funding & 175 & 92.59 & 14 & 7.41 \\
\hline Knowledge & 155 & 82.01 & 34 & 17.99 \\
\hline Lack of information & 43 & 22.75 & 146 & 77.25 \\
\hline Exposure & 172 & 91.01 & 17 & 8.99 \\
\hline Implementation & 129 & 68.25 & 60 & 31.75 \\
\hline Resources & 165 & 87.30 & 24 & 12.70 \\
\hline Curriculum & 106 & 56.10 & 83 & 43.9 \\
\hline Overall & & 71.43 & & 28.57 \\
\hline
\end{tabular}

Table 3 shows the challenges of translating research results into classroom practice. The highest challenge of research results into classroom practice is found to be funding 175(92.59\%). This is closely followed by exposure of research findings for public consumption of 172 (91.01\%). Lack of resources and knowledge of teachers to the use of research results are found to be $165(87.3 \%)$ and 155(82.01\%), while lack of implementation of the research results is found to be $129(68.25 \%)$. This is closely followed by the challenge of curriculum used in Mathematics to be 106 (56.10\%). Lack of information had the least contribution to the challenge of research results of 43 (22.75\%). The overall responses show that there are challenges in translating research results into classroom practice in Mathematics.

Question 4: What are the relative contributions of research challenges to classroom practice?

Table 4: Multiple Regression Analysis showing relative contributions of research challenges to classroom practice

\begin{tabular}{|c|c|c|c|c|c|c|c|c|}
\hline Model & B & $\begin{array}{l}\text { Std. } \\
\text { Error }\end{array}$ & Beta & $\mathbf{T}$ & Sig. $T$ & $\mathbf{R}$ & $\mathbf{R}^{2}$ & $\mathbf{F}$ \\
\hline Constant & 2.544 & 1.032 & & 2.465 & .015 & & & \\
\hline Funding & .060 & .119 & .067 & .503 & .616 & & & \\
\hline Knowledge & .077 & .101 & .080 & .763 & .447 & & & \\
\hline
\end{tabular}




\begin{tabular}{|l|l|l|l|l|l|l|l|l|}
\hline Information & .103 & .110 & .067 & .936 & .350 & .598 & .358 & 14.396 \\
\hline Exposure & .082 & .127 & .075 & .643 & .521 & & & \\
\cline { 1 - 6 } Implementation & .598 & .095 & .048 & 6.328 & .000 & & & \\
\cline { 1 - 1 } Resources & .025 & .103 & .016 & .239 & .811 & & & \\
\cline { 1 - 5 } Curriculum & .056 & .082 & .043 & .687 & .493 & & & \\
\hline
\end{tabular}

Dependent variable: Classroom practice

The regression (model) equation derivable from table 3 is $\mathrm{A}=\mathrm{f}(\mathrm{Rcl})$

$\mathrm{A}=2.544+.060 \mathrm{~B}+0.77 \mathrm{C}+.103 \mathrm{D}+.082 \mathrm{E}+.598 \mathrm{~F}+.025 \mathrm{G}+.056 \mathrm{H}$

Where $\mathrm{A}=$ Classroom practice,$\quad \mathrm{B}=$ Funding,$\quad \mathrm{C}=$ Knowledge,$\quad \mathrm{D}=$ Information

$\mathrm{E}=$ Exposure,$\quad \mathrm{F}=$ Implementation, $\mathrm{G}=$ Resources,$\quad \mathrm{H}=$ Curriculum

Table 4 shows that implementation of research findings has the (best predictor) highest relative contribution to classroom practice with a beta weight of .481 (48.6\%). This is closely followed by teachers' knowledge in translating research results into practice with a beta weight of $0.80(8 \%)$. Exposure of research results has a beta weight of $.075(7.5 \%)$, while funding and dissemination of information of research findings has a beta weight of 0.67 $(6.7 \%)$ in each case. Challenge in the area of implementation of curriculum has a beta weight of $.043(4.3 \%)$ while, the least is lack of resources used for research findings with a beta weight of $.016(1.6 \%)$.

The coefficient of determination which is $\mathrm{R}^{2}$ is .358 . This implies that research challenges accounted for only $35.8 \%$ variation in classroom practice. The remaining $64.2 \%$ variation in classroom practice is largely due to other variables (the regression model) apart from the aforementioned variables of challenges which also affect classroom practice.

The coefficient of correlation $\mathrm{R}$ is .598. It implies that strong and positive relationship exists between variables of research challenges and classroom practice. The regression model is significant in terms of goodness of fit $(\mathrm{Fc}=14.396, \mathrm{P}<0.05, \mathrm{Ft}=2.01)$.

\section{Discussion}

According to the findings, majority of the respondents indicated that they were not aware of research results in teaching methods in Mathematics. Only few of the respondents agreed that they were aware of problem solving method. This finding agrees with the report of (NCTM, 2000; \& Heid, Larson, Fey, Strutchers, Middletor, Gutstein, King \& Tunis, (2006) \& Kilpatrick, 1985) that the main difficulty in translating research results into practice in the classroom is that teachers are too busy to read research papers or read and understand how the methods used in the research can be adapted to classroom practice This is because most research presented are unattractive to teachers. The study also revealed that research results in Mathematics are useful. The findings of Hiebert, (1999); Baroody, (1999) \& Stigler \& Hiebert (1999) corroborate that lessons learned from research for general education students apply. It was also found that, research findings help students develop conceptual 
understanding and skills in a meaningful and purposeful fashion.

Table 3 shows some of the challenges that may not allow practicing teachers to utilize research results in the classroom. NCTM, (2000) stressed that researchers often communicate in a language that teachers do not understand. Some teachers are not interested in reading lengthy research results though they can be of immediate use in the classroom. Other researchers (Lerner, 1997, National Centre for Education Statistics, 1996, Koehler \& Grouws, 1992) reported that, the traditional curriculum does not allow adequate time for the many instructional and teaching strategies necessary for success in Mathematics. Also, curricula do not challenge students to learn important topics in-depth for teachers to display his/her experience and abilities. Clements and McMillen, (1996); Lewis, Perry \& Murata, (2006); Burkhardt and Schoenfeld,( 2003) \& Chappell, (2003) were of the opinion that students who find difficulty in Mathematics need additional resources to support and consolidate the underlying concepts and skills to be learned.

Also from the findings, the study revealed that there was strong and positive relationship between teachers' awareness of research methods and classroom practices in Mathematics. The rationale for this could be based on the difficulty experienced by the teachers in translating research results into classroom practice and the inability to read lengthy research papers on methods that can assist in the classroom practice. As opined by Ale, (1979) \& Hiebert, (1999) on teaching methods that have suffered major neglects by teachers in our institutions of learning is the inability of teachers to improve on the methods and strategies that can be of benefit to the classroom work. Various reasons have been given by various researchers (Clements, 2000 and Burkhardt \& Schoenfeld, 2003) for neglecting this important aspect of teaching that affords students to see what they learn and take part in the teaching and learning process. Some of such reasons include funding and inability to utilize some of the existing research results to improve classroom practice.

The result based on the second hypothesis showed that there was significant and positive relationship between the relevance of research results and classroom practice. Research results when used by teacher help students develop conceptual understanding and improve skills in learning. Having realized the relevance of research results in the teaching and learning process, teachers therefore should improve their ability on reading and using research results to provide better knowledge on practice. The findings of Stiglers and Hiebert, (1999) and Baroody, (1999) agree with the finding in this study

The findings in hypothesis 3 revealed that at $\mathrm{P}<0.05$ implementation of research results has the highest contribution to classroom practice, while the poor predictor of these challenges was found to be lack of resources for research findings. Research challenges of translating research results into classroom practice accounted for only $35.8 \%$ variation. It was also found that a strong and positive correlation existed between variables of research challenges and classroom practice. This finding is in agreement with the studies of Lerner, (1997)\& Koehler \& Grouws, (1992) who stressed the traditional curriculum that will not allow teachers to 
adequately implement research results. Furthermore the result of the study indicated $35.8 \%$ of the variability in classroom practice among the challenges in translating research result into classroom practice is accounted for by a linear combination of the variables of challenges. In summary the results showed that translating research results into classroom practice is usually hampered by poor awareness of the results, finding which was manifested by lack of materials/resources for implementation of research findings and recommendations. This corroborates the findings of Lewis, Perry and Murata, (2006) \& Clements, (2000), Heid et. al, (2006) but this is at variance to the findings of Huberman $(1985,1992)$. There is need therefore, for educators, curriculum planners, government and teachers to agree on how to improve on this in other to ensure better learning outcomes among the teachers and students and among researchers and teachers. This in effect will enhance the acquisition of more skills and interest in Mathematics by teachers and students

\section{Conclusion}

There is a strong need to move closely and link research and practice for the benefit of researchers, teachers and the students' motivation and benefit. The ultimate aim of research is to serve people's well being, the well being of students, teachers and the communities where research is being carried out. Researchers and teachers are independent in efforts to improve the educational experiences of teachers and learners as well. So when they work with purpose together to inform one another's work, it will enhance students' Mathematics learning.

\section{Recommendations}

Based on the findings of this study there is need for improvement towards research in Mathematics education. Mathematics educators as specialists need to engage in more research work which have direct link with the practitioners and instructional practice. Mathematics education researchers should seek to engage in collaborative and meaningful research of mutual interest. Classroom teachers should be more willing to overcome challenges and obstacles regarding research in Mathematics education. When research is collaborative it improves instruction and students' learning. Mathematics education researcher should be willing to work with classroom teachers so as to improve classroom instruction. It is believed that, if adopted and implemented, the findings from these studies are capable of transforming mathematics classroom into the best practices and turn mathematics teachers and their students into mathematics gurus

\section{References}

Ale, S.O. (1979) Difficulties facing mathematics teachers in developing countries . A case study in Nigeria. Educational Studies in Mathematics, 12(1), 479-489.

Baroody (1996). An investigative approach to the mathematics instruction of children classified as learning disabled. In D.K Reids \& W.P. Hresko \& H.L. Swanson 
(eds)

Cognitive Approaches to Learning Disabilities PP. 547-615). Austin, TX:Pro.

Burkhardt, H., \& Schoenfeld A. (2003) Improving Educational Research: Towards a more Useful, more Influential and better funded Enterprise.

Clements, D. H. (2000) Translating lessons from research into mathematics classrooms: Mathematics and special needs students. Perspectives, 26(3); 31-33.

Clements, D.H., \& Mc Millen, S. (1996). Rethinking 'Concrete' anipulative. Teaching Children Mathematics, 2 (5), 270-279.

Chappell, M. (2003) Keeping mathematics front and center: Reaction to middle grades curriculum projects research. In S. Senk \& D. Thompson (Eds), Standards-

Oriented

School Mathematics Curricula: What does the research say about student outcomes?

(PP. 285-296). Mahwah, NJ: Lawrence Erlbaum Associates.

Hiebert, J. C. (1999). Relationships between research and the NCTM standards. Journal for Research in Mathematics Education, 30, 3-19.

Heid M. K; Middleton, J.A; Larson, M; Gutstein, E; Fey, J.T; King, K; Strutchens, M.E \& Tunis, H (2006) The challenge of linking research and practice. Journal for Research in

Mathematics Education, 37(2), 76-86.

Kilpatrick, J(1985). A retrospective account of the past twenty-five years of research on teaching mathematical problem solving. In. E.A. Silver (Ed), Teaching and learning mathematical problem solving: Multiple Research Perspective, (pp. 1-16). Hillsdale, N.J:

Lawrence Erlbaum Associates.

Koehler M. S. Grouws D (1992) Mathematics teaching practices and their effects. In D. Grouws, O (Ed). Handbook of Research on Mathematics Teaching and Learning, $(P P$ 115-126). New York Macmillan.

Laberee, D.F. (2003) The peculiar problems of preparing educational researchers. Educational

Researchers, 32 (4), 13-22. 


\section{Macrothink}

Lerner, J. (1997). Learning disabilities. Boston, M.A: Houghton Mufflin Company.

National Centre for Education statistics (1996). Pursuing excellence, NCES 97-198 (Initial

finding from the thirds International Mathematics and Science Study). www.ed.gov/NCES/timss: Washington D.C: U.S. Government Printing Office.

Lewis, C; Perry, R \& Murata, A (2006). How should research contribute to instructional improvement? The case of lesson study. In Educational Researcher, 35 (3), 3-14.

Stigler, J.W. \& Heibert J. (1999). The teaching gap: Best ideas from the worlds'teachers for Improving Education in the Classroom. New York: The Free Press. 